\title{
The Gait of Hephaistos: Crooked Perceptions into Consilience
}

\section{Los andares de Hefesto: perspectivas torcidas sobre la consiliciencia}

Cheryl De Ciantis

Founder and Principal Consultant

(Kairios - Tucson, Arizona, USA)

Reception date: 19 November 2016

Review date: 3 December 2016

To cite this article: De Ciantis, C. (2017): The Gait of Hephaistos: Crooked Perceptions into Consilience, Icono 14, volumen 15 (1), pp. 128-148. doi: 10.7195/ri14.v15i1.1048 


\section{Abstract}

Depth psychology provides a means to view consilience as an expression of anima mundi, a world 'alive' with consciousness, in which humanity takes part. Mythopoesis becomes an active mode of cognition via the imaginative interaction with the cosmos. The Greek god Hephaistos, crippled god of technology and making, is the paradigmatic possessor not only of consummate technical skill (techne), but also of cunning intelligence and flexible opportunism (metis). Logic places these qualities at opposing ends of a cognitive and behavioral spectrum, but the unique combination of techne with metis, seen in light of another Hephaistean epithet, amphigueeis, an ambiguous term which can be translated either as "crippled" or "ambidextrous," lameness or crooked-walking reveals itself as emblematic of the ability to contain apparent opposites in dynamic tension. The myth of the wounded maker-god becomes a way of perceiving, understanding and reifying the ambidextrous, consilient consciousness needed to navigate a dangerous world.

Key Words: Myth - Hephaestus - Techne - Metis - Mythopoesis - Poesis - Archetype Jung - Hillman

\section{Resumen}

La psicología profunda proporciona una forma de contemplar la consiliencia como una expresión del anima mundi, un mundo "vivo" de conciencia en el que participa la humanidad. La mitopoïesis se convierte en un modo activo de cognición a través de la interacción imaginativa con el cosmos. El dios griego y lisiado Hefesto, dios de la tecnología y la fabricación, es el paradigmático poseedor tanto de la habilidad técnica consumada (techne), como de la inteligencia astuta y el oportunismo flexible (metis). La lógica coloca estas cualidades en extremos opuestos de un espectro cognitivo y conductual. Pero la combinación única de techne con metis, contemplada a la luz de otro epíteto muy de Hefesto, 'amphigueeis', un término ambiguo que se puede traducir como "lisiado" o como "ambidiestro", cojera o andar tortuoso, se revela como emblemática en su capacidad de contener aparentes opuestos en tensión dinámica. El mito del dios hacedor y herido se convierte en una forma de percibir, comprender y reificar la ambidiestra conciencia consiliente necesaria para navegar por un mundo peligroso.

Palabras clave: Mito - Hefesto - Techne - Metis - Mitopoética - Poïesis - Arquetipo Jung - Hillman 


\section{Introduction}

Edward 0. Wilson expanded the original notions of consilience as a means of verifying natural laws to include the evidence of fields of inquiry outside of science, including the arts and humanities. It is both generous and easy to say that science should accept observations from the arts and humanities ("Consilience", n.d.). However, as Charles Percy Snow observed in his 1959 Rede Lecture at Cambridge, the "two cultures" of art and science diverge not only with regard to intellectual aims but also core values concerning what is important in the world ("C.P. Snow", n.d.). The objective aims of science and the subjective and often transgressive aims of the arts comprise profoundly diverse and divergent domains and modes of apprehension, valuing and practice.

Aristotle categorized three ways whereby humans conceptualize material and nonmaterial phenomena: episteme, techne, and phronesis. In order to gain the benefits of consilience we must add a fourth, metis. Metis allows us to think laterally, exceeding the limits of our habitual cognitive categorizations in order to expand our likelihood of attaining adequate understanding of our reality and its consequential meanings in all dimensions of experience. Archetypal psychology provides methods for the metistic movement away from hard, evidence-based conclusions about our reality to a process-oriented engagement with the cosmos. Further, mythopoesis can be seen as an active engagement with reality that gives us useful insights into unities of nonmaterial and material realities, and we may make use of these insights to live life.

The purpose of this article is to present for consideration a largely ignored and overlooked mythic image that contains within itself aspects of both these cognitive and value modes. That image is of Hephaistos, the Greek blacksmith god, the paradigmatic and paradoxical possessor of both techne and metis.

\section{Methods}

This paper takes a depth psychological approach in raising questions about approaches to consilience in order to add to knowledge and practical insights 
with regard to the meanings and consequences of technology as uniquely visible in myth. The mythology of the Greek blacksmith god, Hephaistos, is presented in multiple frames which include historical, etymological, fictional, cultural and psychological, in order to elucidate the dimensions of the combination of techne with metis within a mythic archetype.

\section{Discussion}

\subsection{The Advent of Archetypal Psychology}

In the West, an acceptance of the existence of the unconscious is the intellectual and spiritual heritage of the Romantic movement. However, there remains a dilemma for the modern mind: how to bridge the apparent chasm between the objective, mechanistic worldview of the physical sciences on one hand and subjective, depth psychological interiority on the other (Tarnas, 2007, p.48). The work of Carl Gustav Jung and its subsequent amplification in archetypal psychology envisioned an open-ended realm of interiority capable of change in ways that might ultimately elude fixed categorizations.

Using the Word Association Test originated by Francis Galton, C. G. Jung was led to the concept of 'complexes' (Papadoupoulos, n.d.). For example, the "negative mother complex" is a node around which psychic energy could be demonstrated to coalesce, yielding hypotheses that were useful in subsequent therapeutic treatment (Jung, 1981, p.85-91). What Jung concluded led him away from the Freudian concept of repressed sexual wishes as the universal, organic source of psychopathologies, and toward his ultimate concept of the species-shared collective unconscious and of archetype as the lens by which it may be apprehended.

The collective unconscious [...] appears to consist of mythological motifs or primordial images, for which reason the myths of all nations are its real exponents. In fact, the whole of mythology could be taken as a sort of projection of the collective unconscious.... (Jung, 1970, p.325). 
Jung found that phenomena such as synchronicity, the 'uncanny' and inexplicable occurrences of coincidental events, lead to an ingress of data from the collective unconscious. Other ingresses occur in dreams and hypnogogic or 'threshold' states; in hallucinations resulting from pathology or voluntarily induced by use of 'entheogens;' and also in waking activities such as art-making in which conscious, linguistically represented categories may be suspended if the application of technique and of product are set aside in favor of a state of receptivity. One among Jung's techniques is known as 'active imagination,' whereby an analysand is led to amplify the contents of a manifestation of the unconscious with the goal of deriving meaning that may be applied to individuation, meaning in its simplest terms, coming to terms with and fully living one's unique life and potential. Through active imagination, the concept of archetype can be repeatedly observed in its complex and myriad but thematically discernible features leading to further images and connections which can be examined for a fuller understanding of the interaction of ego, with its constraints, and Self, or soul, which has none. Everything is connected within a unified anima mundi, or world soul, "a transconscious center which must be regarded as a symbol of wholeness" (Jung, 1981, p. 308).

James Hillman, the founder of post-Jungian archetypal psychology, observes that, like anima mundi, the mundus imaginalis, the concept of the 'imaginal world, derived by Henry Corbin from Islamic mysticism, offers "an ontological mode of locating the archetypes [...] as the fundamental structures of the imagination." Mundus imaginalis "provides for archetype a valuative and cosmological grounding [...] different from such bases as: biological instinct, eternal forms, numbers, linguistic and social transmission, biochemical reactions, genetic coding, etc." Thus, the reasoning of archetypal psychology methodology is "rhetorical and poetic," not logical, and "its method is in the cultivation of imagination" (Hillman, 2004, p.15). Hillman presents four 'moves' comprising his re-visioning of psychology: 1) Personifying or Imagining Things; 2) Pathologizing or Falling Apart; 3) Psychologzing or Seeing-Through; 4) Dehumanizing or Soul-Making. Personalizing refers to the natural human wish to see what seems hidden in some kind of representation that refers to the recognizable features of the world. Hillman draws on Plotinus, who reflected on the wisdom of the ancients in creating shrines and statues embodying some aspect of the "All," these serving "like a mirror to catch an image 


\section{MONOGRÁFICO}

of it," and that the souls of men may, for example, see "their images in the mirror of Dionysos" (Hillman, 1976, p.14). By means of Pathologizing, the soul valorizes what we may think of as illness in order to come to grips with "the perplexities of psychic disorder, symptoms and suffering" (p.56). The psyche has "an autonomous ability" to create disorder and "imagine life through this deformed and afflicted perspective" (p.57). Thus what we negatively conceive as pathology must be reimagined as a necessary function of the psyche. Psychologizing, at the core of the pattern and "primary" to the work of the field of depth psychological analysis, means 'seeing-through' in Plotinus' sense, and "examining our ideas themselves in terms of archetypes." (p.126-127). By Dehumanizing, Hillman means the process of detaching from the "moral error" that we must assume individual responsibility for universal human emotions (p.177). Instead, we must recognize their independent existence in the archetypal field. "Rather than looking at myths morally, archetypal psychology looks at moralities mythically" (p.179).

Archetype can be seen as an independently existing, energetic force that attracts self-similar patterns of energy. It is an alterity. This point needs to be made in order to enable us to move laterally when examining myths and other qualitative data in order to come to a deepened understanding. If we take a depth psychological view, this understanding is not to be considered definitively authoritative, or explanatory in a categorical manner. Instead, it assumes, as does psychoanalysis, a process orientation. Fundamentally, archetypal psychology challenges us to accept a co-creative role in reality itself, a process that may have identifiable stages, but has no end. Myth and metaphor are fundamentally present-tense, creative human activities: we are mythopoetic. Without redefining consilience to take these assumptions into account, are we equipped by our constraining logical categories to undertake it?

\subsection{Uses of Myth}

Myths, dreams, fantasies and works of art may be queried to reveal the presence of archetypes. 0ceans of meaning are compressed into the paradoxical vastness of a mytheme. Hillman states that when we lack the perspectives we may derive from mythically constellated archetypes, "we remain in a monotheistic model of 
consciousness which must be one-sided in its judgments and narrow in its vision, for it is unaware of the wealth and variety of psychological ideas" (Hillman, 1976, p.126).

Since Plato and Aristotle, Western philosophy has usually sought to contain myth and isolate it from ethics. Myth, from muthos, or literally, 'mouth,' formerly signified the voice of a god and therefore a legitimate statement of the force underlying all of nature (Lincoln, 1999, p.12). In the time of Hesiod and Homer, the speech of the poet in early Greek tradition was understood as embodying both mythos, the inspiration of the divinity speaking truth, and logos, signifying the worthy craft of the bard whose poetic art sets forth divine truth in the guise of persuasive fiction (p.24). When the pre-Socratics began to envision humans as the crown of creation, their elevation above the gods rendered the old myths illegitimate, at best restricted to the infantile domain of nurseries and old wives' tales, at worst a corrupter of the natural order of authority and proper conformity in the polis. Xenophanes condemns the old tales of the Titans and Centaurs and the "blameworthy" acts of the gods as potentially undermining the civic values of "marriage, the family, law, commerce". He praises instead "wellspoken mythoi," that is, stories of human rather than divine origin, that are " moral in their content, reverent in their attitude, and socially beneficial in their consequences" (Lincoln, 1999, p.28-29). Indeed the poetic logos of Hesiod and Homer is negatively characterized as "guilefully seductive" (p.6). This is the opposite of forthright masculine force, and 'seductive' logos is also the language of the coward who, hiding behind words, evades battle; or of the sophist whose rhetorical tricks subvert truth, and of women p.9). Critias cynically justifies the use of a false logos as a morally justifiable tool of the state. A story may be intentionally designed to arouse fears that control a population within the privacy of their own minds, in such a way that laws cannot, as they are enforceable only in the outer, public sphere (Lincoln, 1999. p.35-37). Power should accrue naturally to the capable and privileged masculine elite which Plato metaphorically likened to those who are straight of gait, meaning that their minds were unswervingly devoted to the truth of philosophy, and that their patrilineal lineage was impeccable. Those whose minds were unsusceptible to this truth were corrupted and their thinking illegitimate and bastardized (Detienne and Vernant, 1978, p.211). 


\section{MONOGRÁFICO}

Though Homer calls him a son of Zeus, as indeed all gods and men are 'sons' of the patriarchal ruler, Hesiod tells us that Hephaistos is the son of Hera alone, by means of parthenogenesis, or virgin conception (De Ciantis 2005, p.107-109). Lacking a biological father, Hephaistos can be said to be a bastard. Possessing metistic magic and trickery, the Hephaistean archetype is inimical to the stable, ordered Republic.

\subsection{Mythic Metis}

Metis, translatable into English most concisely as "cunning intelligence," has been shown to be quite familiar within the Greek world of ideas, culture and values. Although there is ample evidence of its persistence and ubiquity as a "category of mind" for the ancient Greeks, the classicists Marcel Detienne and JeanPierre Vernant (1978) also point out that it had not heretofore been explicitly defined nor had any theoretical description of it been written. Metis is traceable in story, image, and metaphor; through evidences,

[...] as different from each other as are a Theogony and a myth about sovereignty, the metamorphoses of a marine deity, the forms of knowledge of Athena and Hephaestus, of Hermes and Aphrodite, of Zeus and Prometheus, a hunting trap, a fishing net, the skills of a basket-maker, of a weaver, of a carpenter, the mastery of a navigator, the tricks of a crafty character such as Odysseus, the back-tracking of a fox and the polymorphism of an octopus, the solving of enigmas and riddles and the beguiling rhetorical illusionism of the sophists (p.2).

Two of its key images in Greek myth are the circular snare and the twisted gait. The snare is an invisible trap which surrounds a victim unaware and is suddenly drawn tight, binding the victim in an inescapable circular bond. In the Odyssey the Greek blacksmith god, Hephaistos, informed of the infidelity of his wife Aphrodite, sets a snare for her together with her miscreant partner, Ares. He forges a circular net of chains "gossamer-fine as spider webs no man could see, not even a blissful god" and sets the trap over the dishonored marriage bed (Homer, Odyssey 8, p.318-9). He then adopts the strategy of a twisted or circular gait. He ostensibly leaves his forge and his wife to take a vacation, and instead 
circles back around in order to reap the fruits of capture in his trap, calling out the rest of the Olympians to witness. This mental circularity echoes his own physicality. Perhaps the most distinctive Homeric epithet of Hephaistos is periklutos amphigueeis, or "the renowned cripple" (Vernant and Vidal-Naquet, 1990, p.210). Homer also calls him kullopod ("club-footed") (De Ciantis, 2005, p.99). These epithets are nearly unique in ancient Greek literature and are used to evoke no other god. The gait of Hephaistos though haltingly forward would also describe a twisted progression, as one crippled leg and then the other is dragged in a half-circular motion as he walks. The key metistic image, expressed in the metaphor of a reversed, circular, or skewed gait is connected with a propensity to "bend in every conceivable way" to take whatever direction may be to one's advantage (Detienne and Vernant, 1978: 6). Contests may be won by metis where sheer strength is lacking; strategy is served by vigilant watchfulness, enabling the possessor of metis to take advantage of the opportunity for surprise or trickery (p.14). And, metis in its very essence is illusion and deceit (21). However, foremost, to be effective metis assumes the possession and mastery of a techne (De Ciantis, 2005, p.49-50).

Though Hephaistos cannot shapeshift away from his mythically irreversible and irremediable embodiment as the only crippled Olympian god, he nevertheless partakes of the oceanic lineage of Thetis, his foster-mother, with whom in the company of her cousin Eurynome, he spends his childhood and apprentice years under the ocean, thus his archetype incorporates the metistic inheritance of the generations of 0keanus. Metis, who gives her name to the complex, shapeshifts to avoid the violence of Zeus, who swallows her and thereby acquires a taste of the metis she has bequeathed to her daughter, Athena. Thetis shapeshifts to avoid the embrace of the mortal Peleus, who must hold and capture her in order to marry her at the behest of Zeus. We all recognize from experience and from cultural representations the crafty opportunist who is readily capable of the swerve in thought and of directing her or his behavioral trajectory toward a rapidly redefined goal-too often recognizing metis only after we have been ensnared by it. 


\subsection{Hephaistos Klutotechnen, Hephaistos Klutometin, Daidalic Hephaistos}

Among the twelve Olympian gods of the pantheon ruled by Zeus, Hephaistos is the Maker, and the catalogue of his creations is vast, from the bronze mansions of the Olympian gods to the scepter of Agamemnon, the fateful necklace of Harmonia and the thunderbolts of Zeus. The so-called Homeric Hymns-so called because they appear fully two centuries after the Homeric epics-include the brief Hymn to Hephaistos:

Sing, clear-voiced Muse, of Hephaestus famed for inventions [klutomêtin]. With bright-eyed Athena he taught men glorious crafts throughout the world-men who before used to dwell in caves in the mountains like wild beasts. But now that they have learned crafts through Hephaestus the famed worker [klutotechnên], easily they live a peaceful life in their own houses the whole year round. Be gracious, Hephaestus, and grant me success and prosperity! (The Homeric Hymns, 1914, 20, p.1).

Thus, Hephaistos is honored both for his metis and his techne. The requirements of the "Homeric conception" of techne comprise the following: 1) it represents a bounded area of expertise (e.g., weaving, shipbuilding), the mastery of which may be judged authoritatively; 2) it is productive, resulting in something tangible; 3 ) it is applied (one has not only to know it but perform it); 4) its results are visible to the populace at large as evidence of attainment of a specialized skillset; 5) it is rational and transmissible through explanation (Roochnik, 1996, p.26). As the Hymn relates, the god of technology partakes in a métier which has replicable aspects. He is also specifically concerned with the welfare of mortals, and indeed his position in Athens, one of his principal cultic sites, places him in the center of its artisan community as patron. His temple in Athens (today the single best-preserved of all ancient Greek temples) sits below the Acropolis, at the edge of the Keramikos, the district named for its resident craftsmen, who were vital to the economy of the city.

His connection with mortals, however, is deeper than his patronage of techne. The single longest scene in the Iliad featuring Hephaistos comprises the final 
third of Book 18. Patroclus has donned the armor of Achilles and met his death at Hector's hands, spurring Achilles at last to enter the battlefield after his long resistance. Thetis obtains his agreement to wait, vowing to return by sunrise "bearing splendid arms from Hephaestus, god of fire!" (Homer, 1990, 18, p.161-162). When Thetis arrives on Olympus at Hephaistos' bronze mansion, she finds him at work, "sweating, wheeling around his bellows, pressing the work on twenty threelegged cauldrons" designed to deploy at a simple nod of his head (18, p.432-435). "Thetis-here?" he exclaims.

Thetis saved my life

When the mortal pain came on me after my great fall,

Thanks to my mother's will, that brazen bitch,

She wanted to hide me-because I was a cripple.

What shattering anguish I'd have suffered then

If Thetis had not taken me to her breast, Eurynome too,

The daughter of Ocean's stream that runs around the world (18, p.461-467).

Thetis and Hephaistos share a unique bond among the gods, having two aspects. One is the significance of the 'mortal pain' that both have suffered, Hephaistos through his crippled state but also through his mother's rejection; Thetis suffers having been compelled to marry Peleus, a mortal who will suffer the horrifying depredations of aging, and giving birth to her beloved son, Achilles, who though half-divine, will not be granted immortality. Secondly, both possess the rare ability to persuade, which is the only access to power on the part of those who are physically or politically weak, expressed in what may be termed seductive logoi. Hephaistos though weaker in both body and political power may nevertheless speak truth to Zeus, clothed in irony and self-deprecating humor, when the other gods dare not. Thetis has the power to persuade Zeus, in the opening Book of the Iliad, to risk his plans and the dangerous wrath of Hera for the sake of Achilles, Thetis's son. Both Hephaistos and Thetis have the metistic power to move things sideways, so that the trajectories of other actors are altered.

Hearing the appeal of his beloved foster-mother, Hephaistos goes to work on the armor for Achilles. The creation of the Shield of Achilles is one of the most 
famous passages of the Iliad. This description (ekphrasis) has retained a lasting glamor in the history of literature, intentionally reflecting not only the poetics of the divine craft of Hephaistos but also the divine (mythos), poetic craft (logos) of Homer (De Ciantis, 2005, p.61-67). In his forge, Hephaistos is assisted by golden girls of his own manufacture, intelligent and having "voice and strength" like living girls (Homer, 1990: 18:488-491). Other creations of Hephaistos have 'voice and strength:' Talos, the bronze man created for King Minos of Crete, and Pandora, the first woman, whom he crafts from earth (and to whom Hermes gives the gift of seductive logoi) (De Ciantis, 2005, p.135). These are also the qualities of the legendary statues of gods created by Daidalos, which were so lifelike it was reputed that they had to be chained down in order to restrain them within their shrines (Detienne and Vernant, 1978, p.142).

The legendary culture hero Daidalos is a mythic embodiment of a very particular set of terms which are used sparingly and specifically in Greek literature beginning with Homer, and like metis, are multivalent. A limited class of objects is described using the terms deriving from the daidal- word set. They are of "intricate and expensive craftsmanship," "well-crafted," or "skillfully wrought" (Morris 1992, p.34). They are most frequently associated with the concept of kleos: the undying glory accorded to the deeds of epic heroes. The term is used to describe certain of the creations of Hephaistos which have fateful import, such as the Shield of Achilles, which becomes the emblem of the turning point in the Iliad, which as Homer tells us is the story of Achilles. Daidalic objects appearing in epic poetry are "glamorous but treacherous" (p.17-18). Not merely objects of admirable craft, they are most often divine in origin and they are game-changing. The nature of the daidalic object begins to give us a deeper appreciation for the nature of Hephaistos' making and the occult aspects of the combination of metis with techne in the Hephaistean archetype.

By tricking Aphrodite and Ares, Hephaistos confounds a nemesis who possesses superior strength and straight legs. Though Ares does not possess metis, Aphrodite does. Those who possess it can be ensnared only by one who possesses it to a greater degree. It is a game-changing trick that results in Hephaistos' return to his rightful place on Olympus and marriage to Aphrodite in the first place. Hephaistos 
sends a magnificently crafted throne to his mother, Hera. As soon as she sits upon it hidden manacles bind her and the throne flies up to the ceiling suspending her upside down, howling. Lacking techne, the Olympian gods are helpless to free her. Hephaistos refuses the summons of Zeus, who sends Dionysos to fetch him. Hephaistos accepts Dionysos' invitation to feast with him, and in a scene likely depicted in a lost 6th century satyr play, Hephaistos is next seen dead drunk, flanked by satyrs and draped over the back of a donkey (Gantz 1993, p.76). He has been ensnared by one whose metis on this occasion has exceeded his own. Dionysos has used his own techne, that of making wine, in this case served unmixed.

\subsection{Deformed Perspectives}

In the final scene of Book 1 of the Iliad, Hephaistos is seated in his place at the table of the Twelve when a violent quarrel erupts between Zeus and Hera. Zeus has made an agreement sub rosa with Thetis to delay his intended outcome at Troy long enough for her son Achilles to enter the fight and thereby attain everlasting glory since even though child of a goddess he has been denied immortality itself. The Iliad is in great part a celebration of the Greek idea of glory and fame (kleos) as a measure of immortality in the memories of men. Hera, having her own agenda, can tolerate no delay in the destruction of the Trojans and is undermining Zeus's plans. In his anger, Zeus threatens all the gods. Only Hephaistos has the temerity to defend his mother and the others. Employing a method not unlike that which was the sole privilege of a medieval jester, he addresses Hera, urging her to back down, to "stroke the Father with soft, winning words," also subtly mocking Zeus to his face. "Patience, mother! [...] bear up, or dear as you are, I have to see you beaten right before my eyes," for what could he, her son, do against the strength of Zeus?

You remember the last time I rushed to your defense?

He seized my foot, he hurled me off the tremendous threshold And all day long I dropped... (Homer 1990, 1, p.706-713).

Hephaistos then takes up the wine decanter to refill each cup, and his grotesque, crooked gait burlesques the grace of Zeus's cupbearer Ganymede, thereby 
provoking laughter, nervous at first then relieved and at last merrily raucous, from the assembled gods. On evidence of this scene, Hephaistos is said to be a peacemaker, gentle and mild of spirit as he is weak of limb. He is not always so. Called to Troy by Hera when the enormous river god Xanthus threatens to drown Achilles and all the Greeks, Hephaistos turns implacable fire upon him until the god is shrunken to a trickle within his steaming banks, calling for mercy. Hephaistos, his job done, simply leaves (De Ciantis 2005, p.99-102).

There is an undertone of fiery anger in the blacksmith image, and no wonder. Hera conceives and gives birth to him in anger and then rejects him because he "was weak among the gods, and his foot was shriveled, why it was a disgrace to me, a shame in heaven, so I took him in my own hands and threw him out and he fell into the deep sea." (Boer 1979, p.168-69). What is clear from the beginning of the god's story is that the wounding of Hephaistos is emphatically doubled: he is crippled (born a cripple or injured grievously, twice being violently thrown), and he has been abandoned, cast out of Heaven, the only god who has felt "mortal pain." There are two wounds to probe in the story of Hephaistos, one physical, one psychological. What are we to take from a mythology that tells us of a wounded god, one who has been dealt pains that only we vulnerable humans should expect as part of our existential fate?

Disability and pain compress the human psyche into deformed perspectives relative to the ordinary, daily concerns of the abled. Though modern Western literature has mostly ignored Hephaistos, the growing literature of the Disabled community, which increasingly includes not only therapists and caregivers but Disabled speaking for themselves, has made use of the myth of the wounded god as a signal image of the anger and suffering as well as the unique insights and paradoxical abilities made available to them through sheer difference. From them we learn that one aspect of bearing a congenital deformity is guilt on the part of the parents and anger on the part of the child, and that the state of disability attracts insinuations of social impotency (Kriegel 1998: 59-79), which reflects a deeper, mythic suspicion of sexual difference from the norm, both on the part of the parent and the damaged offspring (Sinason 1999, p.183). 
Hephaistos' impairment in itself-he is variously described by ancient authors as ugly, dwarfish, deformed-can be seen as visibly emblematic of the transgressiveness of magic. Hephaistos is a member of a brotherhood of ancient metalsmiths. Their archaic identities have left faint and shadowy traces in fragmentary mythemes: the Daktyls (perhaps named for the fingers of the hand and who performed fearsome magic), the Telchines, even more ill-defined, the pre-Homeric Cyclopes who for a crime against the interests of Zeus were demoted from smiths to pastoralists long before Odysseus encountered Polyphemus, the Cretan Kouretes whose brazen noisemaking saved Zeus in his cradle from discovery and devouring by Kronos (Gantz 1993, p.147). The ancient and persistent fairytale Dwarves, also archetypal smiths and makers of magical objects, are secretive and irascible, sometimes helpful but also dangerous, and certain of their kind are known to steal children as they cannot reproduce on their own. Hephaistos does not produce children as do many of the other gods, and there is a whiff of the sexual deviant about him, as when he clumsily fails to seduce Athena.

The Hephaistean epithet amphigueeis is ambiguous term which can be translated either as "crippled" or "ambidextrous" (Vernant and Vidal-Naquet 1990, p.210). The blacksmith in European cultures traditionally occupies the crossroads where he equally serves all comers, whose aims may themselves be at odds: the hunter whose spear feeds the community with the bounty of his catch; the farmer whose plowshare assures the eventual harvest; the soldier whose weapon must remain sharp; the ruler whose all-important emblems of power-the crown and scepter-are fashioned of noble metals by the smith's skilled hand (De Ciantis 2005, p.13). Traditionally, binding oaths may be undertaken upon his anvil. The blacksmith's perspective is both of the center and at the periphery at once, belonging fully to neither.

Metallurgy was in effect the 'rocket science' of the ancient Mediterranean, and those who possessed its techne were both sought-after for their skills and feared for their manifest 0therness. As Arthur C. Clarke noted, "Any sufficiently advanced technology is indistinguishable from magic" (2000 p.14). We can now begin to see more deeply into the daidalic significance of this archetype of technology and to guess why advanced technologies are viewed with such deep suspicion and not a little fear. 


\subsection{Cognitive Binaries}

The concept of metis has remained largely 'tacit' in the West, both with regard to its qualities as well as, until recently, its scant literary and psychological description. Metis has never taken its place alongside the Aristotelian categories of knowing, where it belongs as a fundamental cognitive category but defies easy placement by dint of its tendency to walk crookedly and evade snares. Behavioral psychology has demonstrated the existence of a number of human traits. The term "Innovative" has been given to a set of coherent characteristics that include novel and copious idea generation and disregard for social structures such as managerial hierarchies with defined roles and rules, and cognitive structures such as the constraints of a given problem definition. However, Innovation is placed on a linear continuum in opposition to another factor termed Adaption, which is characterized by a receptive relation to external structures and preference for efficiency with regard to ideation and practical methods. In other words, fewer ideas, that are generated to 'fit' the problem description at hand, and a potentially inhibiting sensitivity toward negative, external evaluation and its possible consequences. The more "innovative" one is, the less "adaptive" and vice-versa ("Introduction to Adaption-Innovation", n.d.). Innovation may also correlate positively with high Openness to experience (inventive/curious vs. consistent/cautious) and Adaption with high Conscientiousness (efficient/organized vs. easy-going/careless), two of the "Big Five" personality traits (Toegel and Barsoux 2012, p.51-60).

The Innovation factor and others similarly described in behavioral research could give us a measure of metis. Except for one important aspect: Innovation precludes Adaption but metis includes techne. Not only does metis signify the ability to shapeshift at will, transgressing boundaries (Innovation; Openness to experience), but also the application of skill attained through repeated effort and observation of effects and consequences (Adaption; Conscientiousness). One does not approach the volcanic heat of the blacksmith's forge without preparation.

We do witness these discrete characteristics exhibited in the human arena. This does not however preclude the ability to find these characteristics combined, for example when individuals possessing Innovative characteristics may achieve 
a synergistic working relationship with those who are Adaptive. Less frequently, these characteristics may be combined in a singular individual who may be capable of both kinds of ideation, capable of accepting structured problem definitions or ignoring them based on the needs of a situation, and choosing either to persevere in efficient processes yielding short term results or to tolerate ambiguities that are unresolvable in the moment. Hephaistos, with his crooked gait and deformed perspective, gives us both.

\subsection{Mythopoetic Cognition}

What myths meant to their unknown originators is unrecoverable, but humans remain myth-makers, and myths remain alive. Mythopoesis, though combining two ancient Greek terms: mythos and poeisis, is of modern coinage, meaning "myth-making." F. Max Müller, the nineteenth-century mythographer, and Lucien Lévy-Bruhl, the early twentieth-century philosopher, psychologist, and ethnologist, used the term mythopoesis to characterize what they supposed to be a feature of primitive human thought, "wherein myth and metaphor, rather than the supposedly laterdeveloped science and logos, became dominant" (Doty 2000a, p.20). Joseph Campbell explains that the central purpose of myth is to enforce a moral order within each successive coherent social group: "The rise and fall of civilizations in the long, broad course of history can be seen to have been largely a function of the integrity and cogency of their supporting canons of myth" (1968: 5). However, a mythic canon persists for only as long as it has the power to inspire individual members of a group to experience a harmonious connection with the social order and their place in the universe. When it ceases to hold meaning for at least some members of the group or produces "deviant" effects, it instead gives rise to both a sense of dissociation and an urge toward a renewed quest for "meaning". Historical times of dissolution call for new myths that redirect energy toward a new trajectory and allow old shells that no longer carry meaning to drop away.

Moreover, when a creative change comes, it originates with individuals. Campbell's "creative mythology" arises from the "insights, sentiments, thought, and vision of an adequate individual, loyal to his own experience of value" (p.7). Similarly, the literary critic Harry Slochower asserts that mythopoetic works such 
as the Sophoclean tragedies, the Book of Job, The Divine Comedy, Don Quixote, Moby Dick, The Magic Mountain, and others, "arose when the literal account of the legend could no longer be accepted. They arose in periods of crisis, of cultural transition, when faith in the authoritative structure was waning" (Slochower 1970, p.15). However, the artist, novelist and poet, Chris Baldick challenges this "Romantic" notion. Essentially new myths, created in modern times-Faust, Don Quixote, Robinson Crusoe, Frankenstein, Jekyll and Hyde, Dracula-must be considered as expressions of a larger cultural impulse and not only of the visions of the individual creator. As a prime example, the social roots of the Frankenstein 'myth' in its literary creation by Mary Shelley can be traced half a century backward to the metaphors arising out of the social and political upheavals of the French Revolution and its aftermath that condemned the human "monstrousness" of the revolutionaries as well as abuses of the system they meant to abolish (Baldick 1987, p.16-17). Social conditions generate new myths that "live" us as individuals in the sense of Jung's great question, in Memories, Dreams, Reflections, What myth is living me? (Jung 1989, p.171). Each successive overarching mythos functions dialectically, both prescribing social behaviors and calling for correctives. The mythologist William Doty observes that both the backward looking and forward looking aspects of "rituals, symbolic images and myths establish conservative benchmarks, but at the same time they anticipate forms of the future as they determine and shape ideals and goals for both individual and society" (Doty 2000b, p.258).

Poiesis means "making," and the efforts of the mythic blacksmiths issue in visible creations - one of the demands of techne as the Greeks understood it-and also archetypally manifest in the tricky and polyvalent nature of their fiery métier. Mythopoesis may be said to be an activity belonging uniquely in the domain of the Hephaistos archetype and the blacksmith cohort as it appears in myths worldwide.

\section{Conclusions}

According to very recently published research findings, "The Blacksmith and the Devil" may be the oldest of all identifiable story memes, reaching far into prehistory ("Fairy Tale" 2016, n.p.). The basic plot is that a mortal, tempted by a devil or daemon, djinn or witch-an Adversary-to exchange a job of work or a talent 
the Adversary lacks for a promise of wealth or fame or immortality, succeeds in turning the tables and evading the trap, sometimes in turn trapping the Adversary instead. Why the Blacksmith? We live in a "VUCA: world, increasingly characterized by volatility, uncertainty, complexity, and ambiguity" (Jacobs 2006, p.11-12). We may plan strategies to deal with these conditions, but strategies must be equal to the metistic essence of the challenges we face. This is no easy proposition; it is risky and fearsome. The purpose of this paper is not to form conclusions but to raise questions. What questions must we ask ourselves in order to achieve the insights of consilience? What is the very nature of how we must define consilience in light of the challenges of holding the larger project in front of us as it changes shape before our very eyes? Let us ask the Blacksmith, who contains opposites in dynamic tension even while manifesting the made things that make human life bearable and, ultimately, good.

\section{References}

Baldick, Chris (1987). In Frankenstein's Shadow: Myth, Monstrosity, and Nineteenthcentury Writing. 0xford: Clarendon.

Boer, Charles, Trans (1979). The Homeric Hymns. Woodstock: Spring.

"C. P. Snow: The Two Cultures" (n.d.) Age-of-the-sage.org. Retrieved from http:// www.age-of-the-sage.org/scientist/snow_two_cultures.html.

Campbell, Joseph (1968). The Masks of God: Creative Mythology. New York: Penguin. Clarke, Arthur C. (2000). "Hazards of Prophecy: The Failure of Imagination." Profiles of the Future: An Enquiry into the Limits of the Possible. London: Orien Books. "Consilience (Book)" (n.d.). Wikipedia. Retrieved from https://en.wikipedia.org/ wiki/Consilience_(book).

Crudden, Michael, Trans. (2001). The Homeric Hymns. Oxford World's Classics. 0xford: 0xford UP.

DeCiantis, Cheryl (2005). The Return of Hephaistos: Reconstructing the Fragmented Mythos of the Maker. Pacifica Graduate Institute. Ann Arbor: ProQuest/UMI. (Publication No. 3173606).

Detienne, Marcel, and Jean-Pierre Vernant (1978). Cunning Intelligence in Greek Culture and Society. Trans. Janet Lloyd. Atlantic Highlands: Humanities. 


\section{MONOGRÁFICO}

Doty, William G. (2000a). Mythography: The Study of Myths and Rituals. 2nd. ed. Tuscaloosa: U of Alabama P.

(2000b). "What Mythopoetic Means." Mythosphere 2.2: 255-62.

"Fairy Tale Origins Thousands of Years Old, Researchers Say" (2016, January 20) .BBC News. Retrieved from http://www.bbc.com/news/uk-35358487.

Gantz, Timothy (1993). Early Greek Myth: A Guide to Literary and Artistic Sources. Baltimore: The Johns Hopkins UP.

Hillman, James (2004). Archetypal Psychology: A Brief Account. Uniform Edition of the Writings of James Hillman. Vol. 1. Putnam, CT: Spring Publications.

(1976). Re-Visioning Psychology. New York: Harper.

Homer (1990). The Iliad. Trans. Robert Fagles. New York: Penguin.

(1996). The Odyssey. Trans. Robert Fagles. New York: Penguin.

"Introduction to 'Adaption-Innovation in the Context of Change"' (n.d.). KAI Centre. Retrieved from http://www.kaicentre.com/.

Jacobs, T. Owen (2006). Strategic Leadership: The Competitive Edge. Rev. ed. Washington, D.C.: National Defense University.

Jung, C. G. (1989). Memories, Dreams, Reflections. Ed. A. Jaffé. New York: Vintage. (1981). The Archetypes and the Collective Unconscious. Collected Works of C.G. Jung. Rev. by R. F. C. Hull of trans. by H. G. Baynes. Vol. 9 Part 1. Princeton: Princeton UP.

(1970). The Structure of the Psyche. Collected Works of C. G. Jung. Rev. by R.

F. C. Hull of trans. by H. G. Baynes. Vol. 8. Princeton: Princeton UP.

Kriegel, Leonard (1998). Flying Solo. Boston: Beacon.

Lincoln, Bruce (1999). Theorizing Myth: Narrative, Ideology, and Scholarship. Chicago: U of Chicago P.

Morris, Sarah P. (1992). Daidalos and the Origins of Greek Art. Princeton: Princeton UP.

Papadoupoulos, Renos K. (n.d.). “Word Association." International Dictionary of Psychoanalysis. Encyclopedia.com. Retrieved from http://www.encyclopedia. com/medicine/psychology/psychology-and-psychiatry/word-association-test. Roochnik, David (1996). Of Art and Wisdom: Plato's Understanding of Techne. University Park: Pennsylvania State UP. 
Sinason, Valerie (1999). “Challenged Bodies, Wounded Body Images: Richard III and Hephaestus." In Splintered Reflections: Images of the Body in Trauma: 183194. Eds. Jean Goodwin and Reina Attias. New York: Basic Books.

Slochower, Harry (1970). Mythopoesis: Mythic Patterns in the Literary Classics. Detroit: Wayne State UP.

Tarnas, Richard (2007). Cosmos and Psyche: Intimations of a New World View. New York: Plume/Penguin.

The Homeric Hymns and Homerica with an English Translation by Hugh G. EvelynWhite (1914). Cambridge, MA: Harvard University Press; London, William Heinemann Ltd. Perseus Digital Library. Retrieved from http://www.perseus. tufts.edu/hopper/text?doc=Perseus\%3Atext\%3A1999.01.0138\%3Ahymn\% 3D20.

Toegel, G. and Barsoux, J. L. (2012). "How to become a better leader". MIT Sloan Management Review. 53 (3): 51-60.

Vernant, Jean-Pierre, and Pierre Vidal-Naquet (1990). Myth and Tragedy in Ancient Greece. Trans. Janet Lloyd. New York: Zone. 